\title{
AGENESIS OF ISTHMUS OF THYROID GLAND: A RARE CASE REPORT IN AN ADULT MALE CADAVER
}

\author{
Vishali.N ${ }^{* 1}$, G. Rajathi ${ }^{2}$, N. Charanya ${ }^{2}$, S.P. Thangaraj ${ }^{3}$. \\ ${ }^{* 1}$ Associate Professor, Ponnaiyah Ramajayam Institute of Medical Sciences, Manamai - Nallur, \\ ECR, Kancheepuram District, Chennai, India.
}

${ }^{2}$ Assistant Professor, Ponnaiyah Ramajayam Institute of Medical Sciences, Manamai - Nallur, ECR, Kancheepuram District, Chennai, India.

${ }^{3}$ Professor and Head, Ponnaiyah Ramajayam Institute of Medical Sciences, Manamai - Nallur, ECR, Kancheepuram District, Chennai, India.

\section{ABSTRACT}

Introduction: The thyroid gland is a highly vascular endocrine gland. The congenital anomalies of thyroid gland includes thyroglossal cyst, ectopic thyroid tissue and rarely agenesis of one of the lobes or isthmus of thyroid gland. One such rare finding observed in the present study which is highly relevant both to the non - operative clinician and in operative surgery.

Materials and Methods: During routine dissection on an adult male cadaver in the department of anatomy, Ponnaiyah Ramajayam Institute of medical sciences, Chennai, we report agenesis of isthmus of thyroid gland.

Results and Discussion: The lobes of the thyroid gland appear to be normal in size, shape and position. Another important rare finding was the presence of levator glandulae thyroideae which arises from the left lobe to the hyoid bone. Agenesis of isthmus and presence of levator glandulae thyroideae from the left lobe might occur due to high separation of thyroglossal duct.

Conclusion: The knowledge of normal anatomy and its variation of this vital endocrine gland is highly essential for physicians and surgeons for the repair of any thyroid ailment and also during tracheostomy.

KEY WORDS: Isthmus, Tracheostomy, Thyroglossal Duct, Levator Glandulae Thyroideae.

Address for Correspondence: Dr. Vishali. N, Associate Professor, Ponnaiyah Ramajayam Institute of Medical Sciences, Manamai - Nallur, ECR, Kancheepuram District, Chennai - 603102 , India. E-Mail: drvishalin@gmail.com

Access this Article online Quick Response code

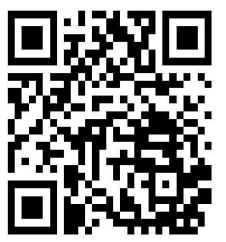

DOI: $10.16965 /$ ijar.2017.491

Journal Information

International Journal of Anatomy and Research

ICV for 2016 ISSN (E) 2321-4287 | ISSN (P) 2321-8967

https://www.ijmhr.org/ijar.htm

Dol-Prefix: https://dx.doi.org/10.16965/ijar

\section{Article Information}

Received: 01 Nov 2017

Peer Review: 01 Nov 2017

Revised: 04 Nov 2017
Accepted: 01 Dec 2017

Published (O): 05 Jan 2018

Published (P): 05 Jan 2018

\section{INTRODUCTION}

The thyroid gland is a highly vascular unpaired endocrine gland. It occupies an important position in the centre of the visceral compartment of the neck, lying astride the trachea just above the thoracic inlet. The gland has two lobes, shaped like slender pears, hugging the anterolateral aspect of the cervical trachea from the level of the oblique line of the thyroid cartilage to the $5^{\text {th }}$ or $6^{\text {th }}$ tracheal ring. The right lobe is often larger than the left and the lobes are joined together across the midline by a thin isthmus plastered quite firmly to the anterior surface of the trachea, at the level of $2^{\text {nd }}$ and $3^{\text {rd }}$ tracheal rings. A small pyramidal lobe may extend from the upper margin of isthmus on the left side and this may be attached to the hyoid bone by a slip of muscular band called Levator 
glandulae thyroideae [1].

The thyroid gland develops as a median down growth of a column of cells from the pharyngeal floor between the first and the second pharyngeal pouches later marked by the foramen caecum of the tongue. The canalized column becomes the thyroglossal duct. The thyroglossal duct passes from the foramen caecum via the substance of the tongue downward in the midline anterior to the hyoid bone. The bilobed lower end of the thyroglossal duct gives origin to the follicular cells of the thyroid gland and the ultimobranchial body gives rise to the parafollicular cells. Most of the part of the thyroglossal duct regress except at the ends, where in the cranial end is marked by the foramen caecum of the tongue and the caudal end may persist as pyramidal lobe and an occasional slip levator glandulae thyroideae [2].

The congenital anomalies of thyroid gland [3] includes.

a. The failure of descend of thyroglossal duct resulting in ectopic thyroid tissue like lingual thyroid, intralingual, suprahyoid, retrohyoid and infra hyoid etc.,

b. The thyroglossal duct may persist as thyroglossal cyst.

c. A thyroglossal fistula may be formed when the cyst breaks through the skin.

d. Rarely, agenesis of isthmus or one of the lobes of the gland leading to confusion in diagnosis, wherein it could be diagnosed as a secreting nodule.

The anatomy and its variation of the vital endocrine gland are relevant both to the non operating clinician and in operative surgery [2]. The present study aims at the case presentation of absence of isthmus of thyroid gland and its clinical and embryological evidence.

\section{MATERIALS AND METHODS}

During routine midline dissection of neck in cadavers for undergraduate medical students at Department of Anatomy, Ponnaiyah Ramajayam Institute of Medical Sciences, Chennai, we reflected the infrahyoid muscles to visualize the trachea and thyroid gland. It was noticed that the two lobes of the thyroid gland were normal in their shape, size and position except for the absence of its intermediate part, the isthmus. We could easily identify and count the upper tracheal rings in the space between the lower part of the lobes which should have come to view only after cutting and reflecting the isthmus. There was no scar mark in neck thus excluding surgical removal. Apices of the lobes extended to the sides of thyroid cartilage deep to the attachment of sternothyroid muscles while base extended up to level of $4^{\text {th }}$ tracheal rings. Upper 4 tracheal rings could be easily identified between the two lobes.

We also identified pyramidal lobe extending upwards from the apex of left lobe and band of fibrous tissue (levator glandulae thyroideae) extending between hyoid bone and pyramidal lobe .Ectopic thyroid tissue was found to be absent. The neurovascular structures (superior and inferior thyroid vessels, superior and recurrent laryngeal nerves) had normal course and relation with the gland. Other structures in the triangle were also normal.

Fig. 1: Showing the anterior view of the dissection of midline structures of neck in an adult male cadaver

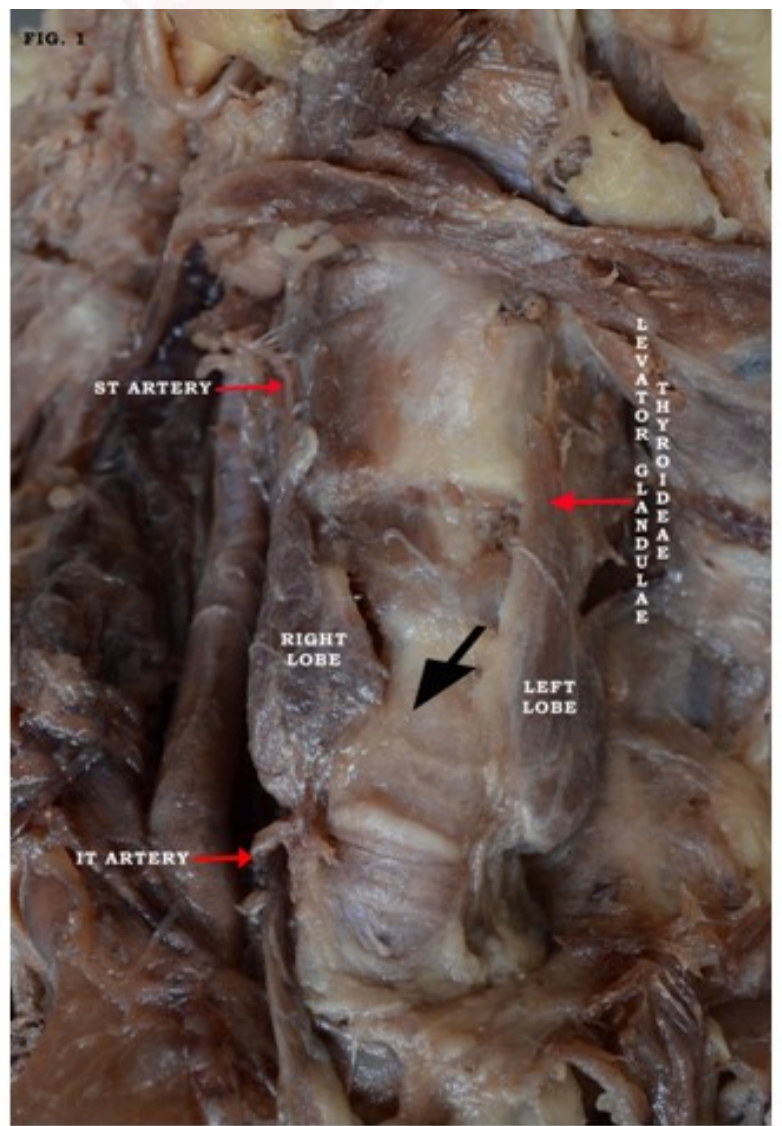

Note: The black arrow indicates the absence of isthmus of thyroid gland between the two lobes.

ST Artery - Superior thyroid artery, IT artery - Inferior thyroid Artery, CT - Cricothyroid, TH - Thyrohyoid. 
Fig. 2: Showing the right lateral view of the midline structures of the neck.

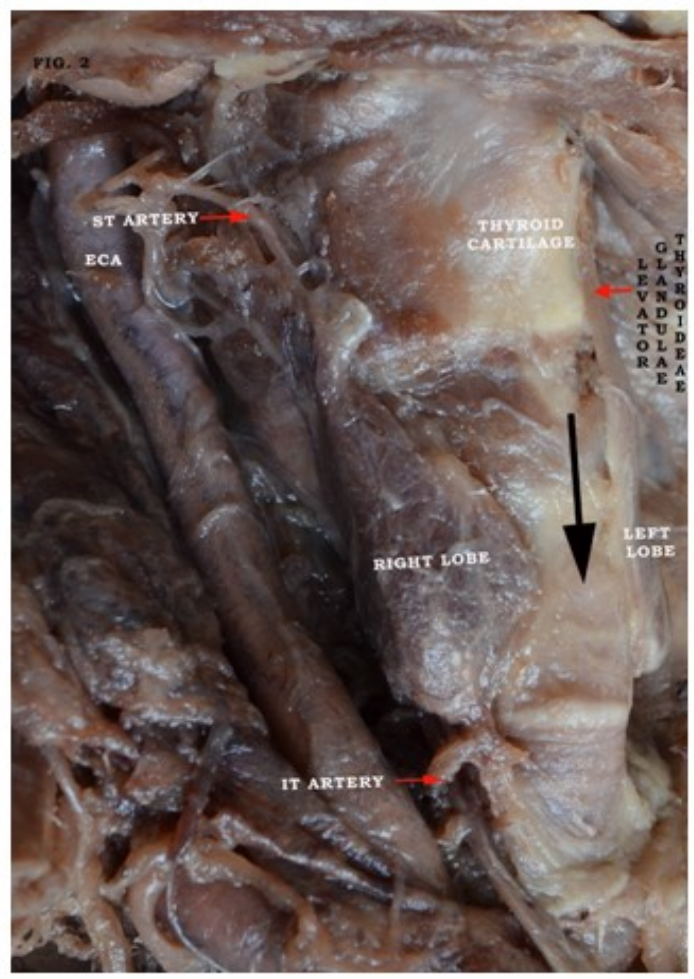

Note: The black arrow indicates the absence of isthmus of thyroid gland between the two lobes.

ST Artery - Superior thyroid artery, IT artery - Inferior thyroid Artery, CT - Cricothyroid, TH - Thyrohyoid.

\section{DISCUSSION}

The thyroid gland is the first endocrine gland to develop in the embryo. It begins to develop 24 days after fertilization. Agenesis of isthmus of thyroid gland is a rare congenital anomaly reported earlier by many anatomists and embryologists [4]. Agenesis of isthmus cannot be identified in patients until referred for some other disease as reported by Omer Faruk [5] in a patient with Grave's Basedow disease and a solitary nodule.

Comparative Anatomy: The isthmus may be missing in amphibians, birds and among mammals - Monotremes, certain Marsupials, Cetaceans, Carnivores and Rodents. In rhesus monkey (Macacus rhesus), the thyroid glands are normal in position but there is no isthmus [6].

Incidence: Incidence of agenesis of isthmus of thyroid gland is found to be $10 \%$ in the present study which correlates with the findings of Archana Belavadi et al. [4], Marshall [6] \& Pastor et al [7]. Comparison of incidence with the other studies in humans has been presented in Table 1. The highest incidence was observed by Ranade et al.,[8] who reported in 35 out of 105 cadavers of which 8 are female cadavers. The least was observed by Won \& Chung [9], who have reported $3 \%$ cases of absence of isthmus and also the lateral lobes were well separated.

Table 1: Comparison of incidence - Agenesis of isthmus.

\begin{tabular}{|c|l|c|}
\hline S.no. & \multicolumn{1}{|c|}{ Author } & $\begin{array}{c}\text { Incidence of Agenesis } \\
\text { of Isthmus of Thyroid } \\
\text { Gland }\end{array}$ \\
\hline 1 & Ranade et al, 2008 [8] & $33 \%$ \\
\hline 2 & Joshi SD et al, 2010 [10] & $16.60 \%$ \\
\hline 3 & Daksha Dixit et al, 2009 [11] & $14.60 \%$ \\
\hline 4 & Marshall,1895 [6] & $10 \%$ \\
\hline 5 & Pastor et al, 2006 [7] & $10 \%$ \\
\hline 6 & Archana Belavadi et al, 2016 [4] & $10 \%$ \\
\hline 7 & Present study (2017) & $10 \%$ \\
\hline 8 & Harjeet et al, 2004 [12] & $7.90 \%$ \\
\hline 9 & Anson, 1996 [13] & $7 \%$ \\
\hline 10 & Braun et al 2007 [14] & $6.80 \%$ \\
\hline 11 & Won \& Chung, 2002 [9] & $3 \%$ \\
\hline
\end{tabular}

Levator glandulae thyroideae: Eisler [1] made an extensive study on the levator glandulae thyroideae and its innervations. He states that the levator of the thyroid gland may be innervated either by ansa cervicalis or through vagus. He has also regarded the levators of the thyroid gland are divisible into three groups viz., the anterior, lateral and posterior levators derived from cricothryoid, infrahyoid and inferior constrictor muscle of pharynx [15]. The levator of the present study may be regarded as the lateral group derived from infrahyoid muscles which seems to be the most common type. Levator glandulae thyroideae extending from the lobe to the hyoid bone is very rare. Presence of this fibro muscular band on the right side has been reported by Kavyashree et al. [16] but in the present study, this fleshy slip arises from the left lobe to the hyoid bone. The knowledge about the fleshy slip of the levator glandulae thyroideae is also very important during neck surgery to avoid the iatrogenic injuries [17]. It is evident from the current study, that there is no pyramidal lobe which usually develops from the caudal end of thyroglossal duct [7] and agenesis of isthmus due to high separation of the caudal end of thyroglossal duct into two lobes. 
Embryological evidence and Genetic impact:

The endodermal component of the primitive pharynx at the level of second and third pharyngeal arch, gives rise to a thyroglossal duct. As it descends down, the caudal end bifurcates and gives origin to the lobes of the thyroid gland and connecting part between them becomes the isthmus while the cephalic end of the duct degenerates. This demarcates it from the pharyngeal endoderm with the end of proliferation of the endodermal cells from which the follicular cells are derived. Occasionally, a high separation of thyroglossal duct can form two isolated thyroid lobes resulting in the agenesis of isthmus [4].

The molecular mechanisms leading to thyroid dysorganogenesis are mostly unknown. Research studies involving murine models and patients emphasised the fact that expression of mutations in regulatory genes (NKX 2.1/T/TF1, FOXE1/TITF2, PAX8, NKX2.5) involved in the developing thyroid results in thyroid dysorgano genesis thus showing that thyroid dysgenesis can be a genetic and inheritable disease. But an isolated isthmus agenesis is very unremarkable $[11,18]$.

Clinical Correlation: Agenesis of isthmus does not produce any evident effect, but probably the anastomostic vessels running on the borders and surfaces of isthmus may also be absent or compromised, thus shutting off the communication between the vessels of two sides, which may result in impaired thyroid function.

Agenesis of isthmus may also be associated with dysorganogenesis resulting in the absence of a part or lobe of the thyroid gland or presence of ectopic thyroid tissue. During partial thyroidectomy, surgeons should make it clear that the other part is functioning well, to avoid resulting in hypothyroidism. On the other side, absence of isthmus may be a fortune for patient requiring emergency tracheostomy, as its absence may avoid cutting and hooking away the isthmus for visualising the tracheal rings[8].

Clinically, the agenesis of isthmus can be diagnosed by scintigraphy, ultra sound, CT and MRI. Findings depicting agenesis of isthmus should proceed for differential diagnosis like autonomous thyroid nodule, thyroiditis, primary carcinoma, neoplastic metastasis and infiltrative diseases like amyloidosis [19].

\section{CONCLUSION}

Agenesis of isthmus of thyroid gland is a rare congenital anomaly which is reported in a male cadaver with no other possible noted complications. Also, Levator glandulae thyroideae arises from the left lobe to the hyoid bone instead of pyramidal lobe. The proper knowledge of normal anatomy and its variation of this vital endocrine gland are highly essential for both physicians and surgeons to correct the thyroid ailment and also requiring airway management for any respiratory pathway obstruction.

\section{Conflicts of Interests: None}

\section{REFERENCES}

[1]. Eisler P, Der M. Levator glandulae thyreoidea und verwandte praelaryngeale Muskelbildungen. Aant Anz 1922; 17: 183-96

[2]. Gag Decker, DJ du Plessis, Lee Mc Gregor's synopsis of Surgical Anatomy, 1999; $12^{\text {th }}$ Edition, Wright Varghese, pp: 198-201.

[3]. Moore KL, Persaud TVN. The developing human, clinical oriented embryology. 6th Ed., Philadelphia, W.B. Saunders Company. 2003; 230-233.

[4]. Archana Belavadi Jagadish et al., A cadaveric study of Agenesis of isthmus of thyroid gland with embryological, genetic bases and clinical significance. Intl. J. Anat. Res. 2016; 4 (2): 2286 - 91.

[5]. Omer FO, Mehmet A, Huseyin T, Faruk O, Oztekin C, Muammer Karaayvaz. Agenesis of isthmus of the thyroid gland in a patient with Graves-Basedow disease and a solitary nodule. Case Rep Surg.2013;608481.

[6]. Marshall CF. Variation in the form of the thyroid in man. Journal of Anatomy and Physiology. 1895;29: 234-239.

[7]. Pastor Vázquez JF, Gil Verona JA, De Paz Fernández FJ, Barbosa Cachorro M. Agenesis of the thyroid isthmus. European Journal of Anatomy. 2006;10(2):8384.

[8]. Ranade AV, Rai R, Pai MM et al. Anatomical variations of the thyroid gland: possible surgical implications. Singapore Medical Journal. 2008;49(10) :831-834.

[9]. Won HS, Chung IH. Morphological variations of the thyroid gland in Korean adults. Korean J Phys Antropol 2002;15:119-125.

[10]. Joshi SD, Joshi SS, Daimi SR, Athavale SA. The thyroid gland and its variations: a cadaveric study. Folia Morphol(Warsz). 2010 Feb;69(1):47-50.

[11]. Daksha D, Shilpa MB, Harsh MP, Ravishankar MV. Agenesis of isthmus of thyroid gland in adult human cadavers: a case series. Cases Journal. 2009; 2 (4,article 6640). 
[12]. Harjeet A, Sahni d, Jit I, Aggarwal AK. Shape, measurements and weight of the thyroid gland in northwest Indians. Surg Radiol Anat 2004;26:91-95.

[13]. Anson BJ. Morris Human Anatomy 12th edition. The Blackinston division Mc Graw Hill Book Co Newyork.1996;168-169.

[14].Braun E, Windisch G, Wolf G, Hausleitner L, Anderhuber $F$. The pyramidal lobe: Clinical anatomy and its importance in thyroid surgery. Surg Radiol Anat 2007;29:21-27.

[15]. Dumont J E, Vassart G. Thyroid Dysgenesis: Multigenic or Epigeneti. Or Both? Endocrinol. 2005;146(12):5035-5037.

[16]. Kavyashree AN et al., Agenesis of isthmus of thyroid gland with presence of pyramidal lobe and levator glandulae thyroideae. Journal of Inernational medicine and dentistry, 2014;1(2):93-96.
[17]. Chaithra RBR, Sreepadma S, Kulkarni MN , Kalghatgi RN. Bilateral Levator Glandulae Thyroideae with Agenesis of Isthmus of Thyroid Gland -A Case Report. Anatomica Karnataka 2012;6(2):81-84.

[18]. De Felice M, Di Lauro R .Thyroid development and its disorders: genetics and molecular mechanisms. Endocr Rev.2004;25:722-746.

[19]. Jamuna, Manimegalai, Aleyamma Fenn, Deborah Joy Hephzibah Agenesis of isthmus of thyroid gland. Innovative Journal of Medical and Health Science. 2013;3(6):266-267.

How to cite this article:

Vishali.N, G. Rajathi, N. Charanya, S.P. Thangaraj. AGENESIS OF ISTHMUS OF THYROID GLAND - A RARE CASE REPORT IN AN ADULT MALE CADAVER. Int J Anat Res 2018;6(1.1):4861-4865. DOI: 10.16965/ijar.2017.491 